\title{
PENGARUH PERUBAHAN STATUS GIZI PASIEN DEWASA TERHADAP LAMA RAWAT INAP DAN BIAYA RUMAH SAKIT
}

\author{
R. Dwi Budiningsari ${ }^{1}$ Hamam Hadi ${ }^{2}$
}

\begin{abstract}
Background: The decline in nutritional status of hospitalized patients was reported to be assossiated with longer length of stay and higher hospital charges. However, the effect of changes in nutritional status on hospital outcomes in Indonesia is still unknown.

Objective: To determine the effect of changes in nutritional status on length of stay and hospital charge among adult hospitalized patients.

Method: A total subjects of 262 adult patients who were admitted to internal and neurology departments of Dr. Sardjito, Dr.M.Jamil, and Sanglah hospitals were included in this study. Nutritional status of each patient was assessed using Subjective Global Assessment (SGA) method. Information on length of stay and hospital charge was collected based on medical records.

Results: Subjects with nutritional status declined from normally to moderately, normally to severely, and moderately to severely malnourished were 6,3 (OR=6.32, 95\% $C l=1,3-29,8) ; 11,9$ (OR=11.94, 95\% Cl=1,02-139,1); and 6,90 (OR=6.9, 95\% Cl=1,5-32,0)times more likely to stay longer than those with nutritional status stayed normal during hospitalitation. They also had 3,3; unlimited; and 1,76 times risk on higher hospital charges than reference group (95\% Cl=1,123-9,529; unlimited; and 0,590-5,245).

Conclusions: The declines of nutritional status from normally to moderately, normally to severely, and moderately to severely malnourished in hospitalized patients influenced to longer length of stay. Normally to moderately and normally to severely malnourished in hospitalized patients influenced to higher hospital charges.
\end{abstract}

Key words: hospital malnutrition, length of stay, hospital charges

\section{PENDAHULUAN}

Besarnya angka prevalensi malnutrisi pada pasien yang dirawat inap telah banyak ditemukan sejak tahun 1970-an (1, 2), juga perubahan-perubahan status gizi yang cenderung menurun selama dirawat inap telah banyak pula dilaporkan $(3,4)$. Penemuan bahwa pasien-pasien malnutrisi mengalami lama rawat inap yang lebih panjang dan menghabiskan biaya lebih tinggi secara signifikan, juga telah terdokumentasi (5,
6). Tidak jarang malnutrisi ini timbul selama dirawat inap di rumah sakit. Penurunan status gizi pada pasien rawat inap, tanpa melihat status gizi pada saat masuk rumah sakit telah dilaporkan berhubungan dengan biaya lebih tinggi dan lama rawat inap lebih panjang (4). Namun pengaruh perubahan status gizi pasien dewasa terhadap berbagai outcome di Indonesia belum diketahui.

Penelitian ini bertujuan untuk mengetahui pengaruh perubahan status gizi pasien rawat inap terhadap lama rawat inap dan biaya rumah sakit.

\section{BAHAN DAN METODE}

Jenis penelitian ini merupakan studi observasional dengan menggunakan rancangan studi kohor prospektif. Subjek penelitian adalah pasien dewasa rawat inap dengan kriteria inklusi: umur lebih dari 18 tahun, makanannya per oral, kesadaran baik selama di rumah sakit, kooperatif, tidak pulang atas permintaan sendiri/pulang paksa, dan bersedia ikut serta dalam penelitian. Penelitian dilakukan di Rumah Sakit (RS) Dr. Sardjito, Yogyakarta, RS Dr. M. Jamil Padang, dan RS Sanglah, Denpasar, Bali dan oleh karena itu penelitian ini lebih dikenal sebagai penelitian SARMILA, singkatan dari Sardjito, Jamil, dan Sanglah. Subjek penelitian terdiri dari pasien rawat inap di bagian Penyakit Dalam dan Saraf dari ketiga RS tersebut dengan kelas perawatan I, II, dan III.

Subjek yang berasal dari RS Dr. Sardjito, RS Dr.M.Jamil, RS Sanglah berturut-turut sebanyak 103 orang (93 orang dari bangsal penyakit dalam dan 10 orang dari bangsal saraf), 92 orang (72 orang dari bangsal penyakit dalam dan 20 orang dari bangsal saraf), dan 154 orang (120 orang dari bangsal penyakit dalam dan 34 orang dari bangsal saraf). Namun sebanyak 86 orang drop out, dengan perincian 24 orang dari RS Dr. Sardjito (21 orang dari bangsal penyakit dalam dan 3 orang dari bangsal saraf), 6 orang dari RS Dr. M.Jamil (4 orang dari bangsal penyakit dalam dan 2 orang dari bangsal saraf), serta 57 orang dari RS Sanglah (49 orang dari bangsal

Program Studi S1 Gizi Kesehatan, FK UGM, Yogyakarta

2 Magister Gizi dan Kesehatan, IKM, Pascasarjana UGM, Yogyakarta 
penyakit dalam dan 8 orang dari bangsal saraf). Dengan demikian maka hanya sebanyak 262 orang di antaranya yang digunakan dalam penelitian ini yaitu yang memenuhi kriteria inklusi tidak pulang atas permintaan sendiri/pulang paksa, tidak pindah bangsal perawatan, dan lengkapnya data biaya. Profil penelitian selengkapnya ditampilkan pada Gambar 1.

\section{(Gambar 1 di sini)}

Data yang sudah di-entry kemudian dianalisis secara deskriptif dan analisis quatitatif menggunakan program Stata 6,0. Status gizi dikategorikan menjadi baik, sedang, dan buruk berdasarkan Subjective Global Assessment (SGA) (7). Selanjutnya berdasarkan perubahan status gizi selama dirumah sakit (status gizi pada waktu masuk dan status gizi pada saat keluar rumah sakit) pasien dikelompokkkan menjadi 9 kelompok yaitu; (1) status gizi baik pada waktu masuk dan status gizi tetap baik pada waktu keluar, (2) status gizi baik pada waktu masuk dan menjadi status gizi sedang pada waktu keluar, (3) status gizi baik pada waktu masuk dan menjadi status gizi buruk pada waktu keluar, (4) status gizi sedang pada waktu masuk dan menjadi status gizi baik pada waktu keluar, (5) status gizi sedang pada waktu masuk dan tetap sedang pada waktu keluar, (6) status gizi sedang pada waktu masuk dan menjadi status gizi buruk pada waktu keluar, (7) status gizi buruk pada waktu masuk menjadi status gizi baik pada waktu keluar, (8) status gizi buruk pada waktu masuk dan menjadi status gizi sedang pada waktu keluar, dan (9) status gizi buruk pada waktu masuk dan tetap dengan status gizi buruk pada waktu keluar.

Kemudian dikategorikan pula ke dalam empat macam perubahan status gizi, yaitu:

Kelompok Normal : Baik menjadi Baik

Kelompok Meningkat : Sedang menjadi Baik, Buruk menjadi Baik, Buruk menjadi Sedang

Kelompok Tetap : Sedang menjadi Sedang, Buruk menjadi Buruk

Kelompok Menurun : Baik menjadi Sedang, Baik menjadi Buruk, Sedang menjadi Buruk

Analisis statistik yang digunakan yaitu uji statistik regresi ganda linier untuk menguji perubahan status gizi sebagai variabel bebas (skala ordinal) terhadap lama rawat inap dan biaya sebagai variabel tergantung (skala rasio, dalam satuan hari dan rupiah). Sedangkan uji statistik regresi logistik digunakan untuk perubahan status gizi sebagai variabel bebas (skala ordinal) terhadap lama rawat dan biaya sebagai variabel tergantung (skala ordinal, lama rawat lebih/sama dengan 7 hari dan kurang dari 7 hari serta biaya lebih dari Rp.1.100.000,-dan kurang/sama dengan Rp.1.100.000,-). Analisis multivariat juga digunakan untuk dapat mengendalikan faktor-faktor luar, yaitu diagnosis penyakit, terapi medis, riwayat hospitalisasi, umur, jenis kelamin, kelas perawatan, asal rumah sakit, langsung/tidaknya masuk rumah sakit, serta asupan energi dan protein. Seluruh analisis statistik dilakukan hanya pada subjek yang pulang dalam keadaan sembuh dan membaik saja, tidak termasuk subjek yang pulang dalam keadaan tidak sembuh, tidak membaik, maupun pulang dalam keadaan mati.

\section{HASIL DAN BAHASAN}

\section{Karakteristik Subjek}

Selama 4 bulan mulai bulan Oktober sampai dengan bulan Februari 2002, ditemukan 318 orang subjek namun hanya 231 orang di antaranya yang tidak drop out yaitu yang memenuhi kriteria inklusi tidak pulang atas permintaan sendiri/pulang paksa, tidak pindah bangsal perawatan, dan lengkapnya data biaya. Namun karena belum memenuhi jumlah minimal subjek kelompok terpapar sebanyak 73 orang, maka dilakukan lagi pengambilan data selama 2 bulan, yaitu pada bulan Juli hingga Agustus 2003. Setelah pengambilan data periode kedua ini, diperoleh penambahan subjek sebanyak 31 orang sehingga jumlah subjek penelitian ini menjadi 262 orang.

Dari tiga indikator status gizi yang digunakan yaitu IMT, TLK, dan SGA, ternyata hanya SGA yang memenuhi jumlah sampel minimal sebanyak 73 orang $(b=0,80)$ bagi kelompok yang mengalami penurunan status gizi. Dengan demikian maka pembagian dua kelompok yang mengalami dan yang tidak mengalami penurunan status gizi selanjutnya hanya berdasarkan indikator SGA. Status gizi awal subjek meliputi status gizi baik dan sedang sebanyak 113 orang $(43,1 \%)$ dan 115 orang $(43,9 \%)$ serta status gizi buruk sebanyak 34 orang $(13,0 \%)$. Pada saat keluar rumah sakit status gizi berubah menjadi status gizi baik sebanyak 152 orang $(58,0 \%)$, status gizi sedang sebanyak 57 orang $(21,8 \%)$ dan status gizi buruk sebanyak 53 orang $(20,2 \%)$.

Terdapat 74 orang subjek $(28,2 \%$ ) yang mengalami penurunan status gizi selama dirawat inap di rumah sakit, 10 orang $(3,8 \%)$ di antaranya pada saat masuk rumah sakit berstatus gizi baik namun mengalami 
penurunan menjadi status gizi buruk pada saat keluar rumah sakit. Subjek yang mengalami penurunan status gizi baik menjadi sedang dan sedang menjadi buruk masing-masing sebanyak 32 orang (12,2\%).

Karakteristik umum subjek ditampilkan pada Tabel 1. Pada kelompok yang mengalami penurunan maupun yang tidak mengalami penurunan status gizi, sebagian besar berumur 48-57 tahun yaitu sebanyak 24 orang $(9,2 \%)$ dan 35 orang $(13,4 \%)$. Pada dua kelompok sebagian besar subjek berjenis kelamin laki-laki yaitu berturut-turut sebanyak 38 orang $(14,5 \%)$ dan 92 orang $(35,1 \%)$. Tidak ada perbedaan antara dua kelompok dalam hal umur dan jenis kelamin $(p>0,05)$.

Baik pada kelompok yang mengalami maupun yang tidak mengalami penurunan status gizi sebagian besar subjek berasal dari bangsal penyakit dalam yaitu berturut-turut sebanyak 56 orang $(21,4 \%)$ dan 155 orang $(59,2 \%)$. Berdasarkan kelas perawatan, ternyata dua kelompok sebagian besar berasal dari kelas III yaitu berturut-turut sebanyak 42 orang (16,0\%) dan 103 orang (39,3\%). Tidak ada perbedaan antara dua kelompok dalam hal bangsal dan kelas perawatan $(p>0,05)$.

Pendidikan subjek sebagian besar termasuk dalam kelompok pendidikan menengah yaitu SMP dan SMA dengan jumlah pada dua kelompok berturutturut adalah sebanyak 35 orang (13,4\%) dan 125 orang $(47,7 \%)$. Pekerjaan subjek pada kelompok yang status gizinya menurun sebagian besar adalah bekerja sebagai PNS/TNI/Polri yaitu sebanyak 21 orang $(8,0 \%)$ sedangkan pada kelompok yang status gizinya tidak menurun sebagian besar dalam kelompok tidak bekerja sebanyak 67 orang $(25,6 \%)$. Dalam hal pendidikan dan pekerjaan, terdapat perbedaan antara dua kelompok $(p>0,05)$.

Pendapatan subjek pada kelompok yang mengalami penurunan status gizi sebagian besar pada kelompok lebih dari Rp. 800.000,-per bulan sebanyak 42 orang (18,3\%), namun sebaliknya pada kelompok yang tidak mengalami penurunan status gizi sebagian besar pada kelompok kurang/sama dengan Rp.800.000,-per bulan sebanyak 87 orang $(37,8 \%)$. Sebagian besar pengeluaran pada kelompok yang mengalami penurunan maupun pada kelompok yang tidak mengalami penurunan status gizi adalah sama-sama lebih dari Rp. 750.000,-per bulan, yaitu berturut-turut sebanyak 52 orang $(22,6 \%)$ dan 99 orang $(43,0 \%)$. Ada perbedaan pendapatan dan pengeluaran antara dua kelompok menurut hasil analisis statistik kai kuadrat $(p<0,05)$.
RS Dr.Sardjito merupakan asal rumah sakit terbanyak pada kelompok yang status gizinya menurun yaitu sebanyak 43 orang $(16,4 \%)$, berbeda dengan kelompok yang status gizinya tidak menurun paling banyak berasal dari RS Sanglah yaitu sebanyak 79 orang $(30,2 \%)$. Ada perbedaan antara dua kelompok $(p<0,05)$ (Tabel 1$)$.

Tabel karakteristik khusus subjek penelitian ditampilkan pada Tabel 2. Sebagian besar subjek pada kelompok yang mengalami dan yang tidak mengalami penurunan status gizi didiagnosis menderita penyakit noninfeksi berturut-turut sebanyak 54 orang $(20,6 \%)$ dan 114 orang $(43,5 \%)$. Sebanyak 38 orang $(14,5 \%)$ dan 97 orang $(37,0 \%)$ di antara subjek dua kelompok mendapatkan tindakan medis selama dirawat inap di rumah sakit. Dalam hal diagnosis penyakit dan tindakan medis, tidak ada perbedaan antara dua kelompok $(p>0,05)$.

Sebagian besar subjek baik pada dua kelompok yang mengalami maupun yang tidak mengalami penurunan status gizi ternyata sebelumnya tidak pernah dirawat inap di rumah sakit dalam 6 bulan terakhir yaitu sebanyak 46 orang $(17,6 \%)$ dan 155 orang $(59,2 \%)$. Juga hanya 7 orang $(2,7 \%)$ dan 5 orang $(1,9 \%)$ di antara subjek dua kelompok yang pernah menjalani operasi dalam 6 bulan terakhir. Ada perbedaan antara dua kelompok $(p<0,05)$ dalam hal riwayat rawat inap dan operasi 6 bulan terakhir.

Asupan energi pada kelompok yang mengalami penurunan status gizi sebagian besar pada kategori kurang dari 80 persen, yaitu sebanyak 47 orang (17,9\%). Namun sebaliknya pada kelompok yang tidak mengalami penurunan status gizi sebagian besar asupan energinya di atas atau sama dengan 80 persen sebanyak 97 orang (37,0\%). Demikian pula asupan protein kategori kurang dari 80 persen sebagian besar ditemukan pada kelompok yang mengalami penurunan status gizi, yaitu sebanyak 45 orang $(17,1 \%)$. Sebagian besar subjek pada kelompok yang tidak mengalami penurunan status gizi mempunyai asupan protein lebih atau sama dengan 80 persen sebanyak 104 orang (39,7\%). Terdapat perbedaan antara dua kelompok dalam hal asupan energi dan protein $(p<0,05)$.

Pada kelompok yang mengalami penurunan dan yang tidak mengalami penurunan status gizi, berturutturut hanya 10 orang $(3,8 \%)$ dan 39 orang $(14,9 \%)$ yang kategori lama rawat inapnya pendek, sisanya 64 orang $(24,4 \%)$ dan 149 orang $(56,9 \%)$ termasuk dalam kategori lama rawat yang panjang. Antara dua 
kelompok subjek mempunyai distribusi lama rawat inap yang sama $(p>0,05)$.

Biaya rumah sakit yang dikeluarkan pasien pada kelompok yang mengalami penurunan status gizi adalah termasuk ke dalam kategori lebih dari Rp. 1.100 .000 ,-yaitu sebanyak 46 orang $(17,6 \%)$ sedangkan pada kelompok yang tidak mengalami penurunan status gizi sebagian besar termasuk ke dalam kategori kurang/sama dengan Rp. 1.100.000,yaitu sebanyak 111 orang $(42,4 \%)$. Tidak ada perbedaan antara dua kelompok $(p<0,05)$.

Tabel 1. Karakteristik Umum Subjek Menurut Kelompok yang Mengalami

Pengaruh Penurunan Status Gizi terhadap dan yang tidak Mengalami Penurunan Status Gizi

\begin{tabular}{|c|c|c|c|c|c|c|c|c|c|}
\hline & \multirow[t]{2}{*}{ Variabel } & \multicolumn{2}{|c|}{$\begin{array}{l}\text { Kelompok yang } \\
\text { Mengalami } \\
\text { St.Gizi } \\
\end{array}$} & \multicolumn{2}{|c|}{$\begin{array}{c}\text { Kelompok yang } \\
\text { tidak Mengalami } \\
\text { St.Gizi } \\
\end{array}$} & \multicolumn{2}{|c|}{ Total } & \multirow[t]{2}{*}{$\chi^{2}$} & \multirow[t]{2}{*}{$P$ value } \\
\hline & & $\mathbf{n}$ & $\%$ & $\mathbf{n}$ & $\%$ & $\mathbf{n}$ & $\%$ & & \\
\hline \multirow[t]{7}{*}{1.} & Umur (tahun) & & & & & & & & \\
\hline & $-18-27$ & 17 & 6,5 & 36 & 13,7 & 53 & 20,2 & 9,7167 & 0,084 \\
\hline & $-\quad 28-37$ & 7 & 2,7 & 32 & 12,2 & 39 & 14,9 & & \\
\hline & $-\quad 36-47$ & 9 & 3,5 & 29 & 11,1 & 38 & 14,5 & & \\
\hline & $-\quad 48-57$ & 24 & 9,2 & 35 & 13,4 & 59 & 22,5 & & \\
\hline & - $\quad 58-67$ & 13 & 5,0 & 33 & 12,6 & 46 & 17,6 & & \\
\hline & $-\quad \geq 68$ & 4 & 1,5 & 23 & 8,8 & 27 & 10,3 & & \\
\hline \multirow{3}{*}{ 2. } & Jenis kelamin & & & & & & & & \\
\hline & - Laki-laki & 38 & 14,5 & 96 & 36,6 & 134 & 51,1 & 0,0018 & 0,967 \\
\hline & - Perempuan & 36 & 13,7 & 92 & 35,1 & 128 & 48,9 & & \\
\hline \multirow[t]{3}{*}{3.} & Bangsal & & & & & & & & \\
\hline & - Peny.dalam & 56 & 21,4 & 155 & 59,2 & 211 & 80,5 & 1,5530 & 0,213 \\
\hline & - Saraf & 18 & 6,9 & 33 & 12,6 & 51 & 19,5 & & \\
\hline \multirow{4}{*}{ 4. 1} & Kelas Rawat & & & & & & & & \\
\hline & - Kelas I & 6 & 2,3 & 12 & 4,6 & 18 & 6,9 & 0,4591 & 0,795 \\
\hline & - Kelas II & 26 & 9,9 & 73 & 27,9 & 99 & 37,8 & & \\
\hline & - Kelas III & 42 & 16,0 & 103 & 39,3 & 145 & 55,3 & & \\
\hline \multirow{4}{*}{ 5. } & Pendidikan & & & & & & & & \\
\hline & - Rendah & 25 & 9,5 & 43 & 16,4 & 68 & 26,0 & 8,4442 & $0,015^{*}$ \\
\hline & - Menengah & 35 & 13,4 & 125 & 47,7 & 160 & 6,1 & & \\
\hline & - Tinggi & 14 & 5,3 & 20 & 7,6 & 34 & 13,0 & & \\
\hline \multirow{6}{*}{6.} & Pekerjaan & & & & & & & & \\
\hline & - PNS/TNI/Polri & 21 & 8,0 & 39 & 14,9 & 60 & 22,9 & 19,6917 & $0,001^{*}$ \\
\hline & - Wiraswasta & 14 & 5,3 & 44 & 18,8 & 58 & 22,1 & & \\
\hline & - Petani,Buruh & 12 & 4,6 & 21 & 8,0 & 33 & 12,6 & & \\
\hline & - Tak bekerja & 10 & 3,8 & 67 & 25,6 & 77 & 29,4 & & \\
\hline & - Lain-Lain & 17 & 6,5 & 17 & 605 & 34 & 13,0 & & \\
\hline \multirow[t]{3}{*}{8.} & Pendapatan & & & & & & & & \\
\hline & - Rendah $(\leq 800000)$ & 27 & 11,7 & 87 & 37,8 & 114 & 49,6 & 4,2935 & $0,038^{*}$ \\
\hline & - $\quad$ Tinggi $(>800000)$ & 42 & 18,3 & 74 & 32,2 & 116 & 50,4 & & \\
\hline \multirow[t]{3}{*}{9.} & Pengeluaran & & & & & & & & \\
\hline & - $\quad$ Rendah $(\leq 750000)$ & 17 & 7,4 & 62 & 27,0 & 79 & 34,3 & 4,1215 & $0,042^{*}$ \\
\hline & - $\quad$ Tinggi $(>750000)$ & 52 & 22,6 & 99 & 43,0 & 151 & 65,7 & & \\
\hline \multicolumn{10}{|c|}{ 10. Asal RS } \\
\hline & - Sardjito & 43 & 16,3 & 36 & 13,7 & 79 & 30,2 & 38,5339 & $<0,000^{*}$ \\
\hline & - Jamil & 13 & 5,0 & 73 & 27,9 & 86 & 32,8 & & \\
\hline & - Sanglah & 18 & 6,9 & 79 & 30,2 & 97 & 37,0 & & \\
\hline
\end{tabular}

Keterangan: * = signifikan dengan $\mathrm{p}<0,05$ 
Tabel 2. Karakteristik Khusus Subjek Menurut Kelompok yang Mengalami dan yang tidak Mengalami Penurunan Status Gizi

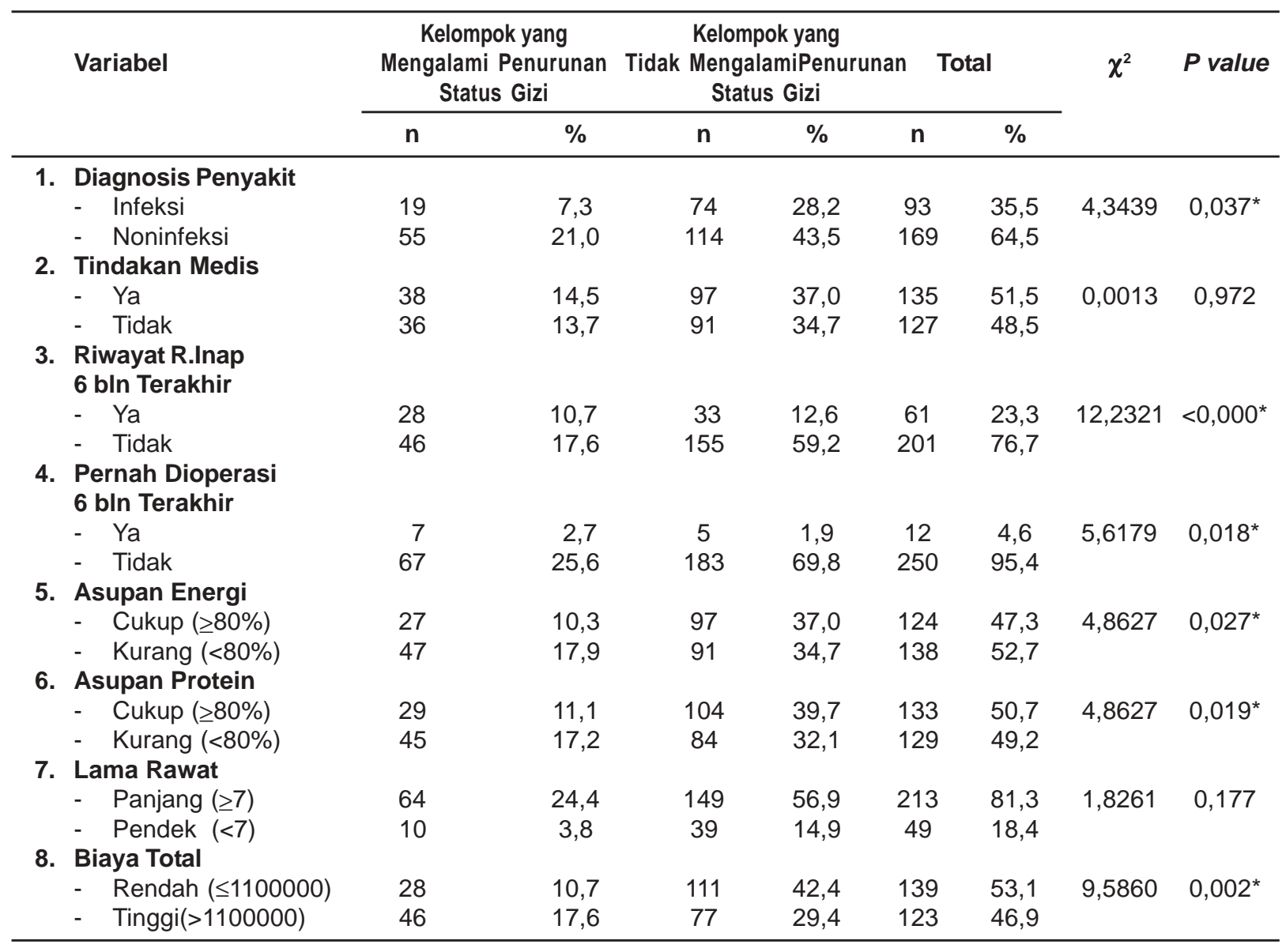

Keterangan: * $=$ signifikan dengan $\mathrm{p}<0,05$

\section{Lama Rawat Inap}

Pengaruh sembilan macam perubahan status gizi subjek terhadap kelompok lama rawat inap (data nominal) ditampilkan pada Tabel 3. Hasil ini diperoleh setelah mengendalikan variabel-variabel luar. Subjek yang mengalami penurunan status gizi dari baik menjadi sedang, baik menjadi buruk, dan sedang menjadi buruk berisiko mengalami lama rawat inap yang lebih panjang sebesar 6,32; 11,94; dan 6,90 kali daripada subjek yang berstatus gizi tetap baik hingga keluar rumah sakit $(95 \% \mathrm{Cl}=1,341-29,813 ; 1,026$ 139,107; dan 1,488-32,024). Hal ini menunjukkan bahwa perubahan status gizi dari baik menjadi sedang, baik menjadi buruk, dan sedang menjadi buruk berpengaruh secara signifikan terhadap lama rawat inap yang lebih panjang.

Berdasarkan empat macam perubahan status gizi, subjek yang status gizinya menurun berisiko mengalami lama rawat inap lebih panjang 7,9 kali daripada kelompok referensi $(95 \% \mathrm{Cl}=2,294-27,180)$.
Sedangkan subjek yang status gizinya meningkat dan tetap, mempunyai risiko mengalami lama rawat inap lebih panjang hanya 2,94 dan 2,56 kali lebih besar daripada kelompok referensi $(95 \% \mathrm{Cl}=1,244-6,925$; 0,596-10,993) (Tabel 4).

Jika lama rawat inap tidak dikelompokkan (data kontinu), maka digunakan uji statistik regresi linier berganda yang juga mengendalikan faktor-faktor luar. Subjek yang berstatus gizi dari baik menjadi sedang, baik menjadi buruk, dan sedang menjadi buruk mempunyai lama rawat inap masing-masing 12, 17 dan 15 hari (vs 9 hari). Hal ini berarti terdapat selisih berturut-turut sebanyak 3,8 , dan 6 hari dibandingkan dengan kelompok referensi (Tabel 5).

Berdasarkan empat macam perubahan status gizi pada Tabel 6, maka subjek yang status gizinya menurun mempunyai rata-rata lama rawat inap 14 hari, berbeda 5 hari dibandingkan kelompok referensi. Sedangkan subjek yang status gizinya meningkat dan tetap, mempunyai rata-rata lama rawat inap 10 hari, 
Tabel 3. Analisis Multivariat Pengaruh Sembilan Macam Perubahan Status Gizi Spesifik terhadap Kelompok Lama Rawat Inap

\begin{tabular}{|c|c|c|c|c|c|c|}
\hline \multicolumn{2}{|c|}{ SGA } & \multirow[t]{2}{*}{ Jumlah } & \multicolumn{3}{|c|}{ Lama Rawat Inap ${ }^{2}$} & \multirow[t]{2}{*}{$\chi^{2}$} \\
\hline Masuk RS & Keluar RS & & OR & $\mathbf{P}$ & $95 \% \mathrm{Cl}$ & \\
\hline Baik & Baik & 72 & 1,0 & & & - \\
\hline Baik & Sedang & 32 & 6,32 & $0,020^{1}$ & $1,341-29,813$ & $0,568^{3}$ \\
\hline Baik & Buruk & 10 & 11,94 & $0,048^{1}$ & $1,026-139,107$ & \\
\hline Sedang & Baik & 68 & 4,20 & $0,005^{1}$ & $1,530-11,507$ & \\
\hline Sedang & Sedang & 14 & 4,41 & 0,194 & $0,470-41,524$ & \\
\hline Sedang & Buruk & 32 & 6,90 & $0,014^{1}$ & $1,488-32,024$ & \\
\hline Buruk & Baik & 12 & 1,31 & 0,744 & $0,264-6,463$ & \\
\hline Buruk & Sedang & 11 & 1,50 & 0,578 & $0,350-6,559$ & \\
\hline Buruk & Buruk & 11 & 1,76 & 0,676 & $0,223-10,154$ & \\
\hline
\end{tabular}

Keterangan: ${ }^{1}=$ signifikan dengan $\mathrm{p}<0,05$ (analisis regresi logistik)

${ }^{2}=$ lama rawat inap $\ddagger$ panjang $=>7$ hari; pendek $=\leq 7$ hari

$3=p>0,05$ (analisis goodness of fit)

hanya berbeda 1 hari dengan kelompok referensi.

Hasil ini membuktikan hipotesis ke-1, ke-2, dan ke-3 sekaligus mendukung hasil penelitian sebelumnya (4) yang menyimpulkan bahwa pasien rawat inap yang mengalami penurunan status gizi dari baik menjadi sedang, baik menjadi buruk, dan sedang menjadi buruk selama di rumah sakit mempunyai ratarata lama rawat inap yang lebih panjang daripada yang tidak mengalami penurunan status gizi. Braunschweig et al (4) menemukan bahwa subjek yang status gizinya baik menjadi sedang, baik menjadi buruk, dan tidak malnutrisi (16 dan 10 hari vs 8 hari).

Secara statistik, pasien yang mempunyai lebih banyak risiko malnutrisi mempunyai lama rawat inap yang lebih panjang $(6,10)$. Subjek yang mempunyai lebih banyak risiko malnutrisi memerlukan waktu rawat inap rata-rata 20,5 hari, hampir dua kali lipatnya dibandingkan dengan subjek tanpa risiko malnutrisi yang hanya memerlukan waktu rawat inap rata-rata 10,8 hari (6). Rata-rata lama rawat inap pasien berisiko malnutrisi 2 hari lebih panjang daripada yang tidak berisiko malnutrisi ( 6 hari vs 4 hari) (10).

Tabel 4. Analisis Multivariat Pengaruh Empat Macam Perubahan Status Gizi terhadap Kelompok Lama Rawat Inap

\begin{tabular}{lccccc}
\hline Perubahan Status Gizi & Jumlah & \multicolumn{3}{c}{ Lama Rawat Inap $^{2}$} & $\boldsymbol{\chi}^{\mathbf{2}}$ \\
\cline { 3 - 4 } & & $\mathbf{O R}$ & $\mathbf{P}$ & $\mathbf{9 5 \%} \mathbf{~ C l}$ & \\
\hline Normal ${ }^{\circledR}$ & 72 & 1 & & & $0,637^{3}$ \\
Meningkat & 91 & 2,94 & $0,014^{1}$ & $1,244-6,925$ & \\
Tetap & 25 & 2,56 & 0,207 & $0,596-10,993$ & \\
Menurun & 74 & 7,90 & $0,001^{1}$ & $2,294-27,180$ & \\
\hline
\end{tabular}

Keterangan: ${ }^{1}=$ signifikan dengan $\mathrm{p}<0,05$ (analisis regresi logistik)

$$
\begin{aligned}
2 & =\text { lama rawat inap } \ddagger \text { panjang }=>7 \text { hari; pendek }=\leq 7 \text { hari } \\
3 & =p>0,05 \text { (analisis goodness of fit) }
\end{aligned}
$$

sedang menjadi buruk mempunyai rata-rata lama rawat inap berturut-turut 16, 23, dan 19 hari (vs 14 hari).

Hal ini juga sesuai dengan penelitian Robinson et al. (9) yang menyimpulkan bahwa lama rawat inap meningkat seiring dengan penurunan status gizi pasien di rumah sakit (12 hari vs 8 hari). Demikian pula Chima et al. (10) yang menemukan bahwa secara statistik, pasien yang mengalami malnutrisi dan borderline di rumah sakit mempunyai lama rawat inap yang lebih panjang 8 dan 2 hari daripada pasien yang
Risiko malnutrisi meliputi kehilangan 10 pon berat badan yang tidak diinginkan dalam waktu enam bulan terakhir, berat badan kurang dari 90 persen dibanding normal menurut jenis kelamin dan tinggi badan, mual atau nafsu makan buruk selama lebih dari lima hari, diit tidak per oral selama lebih dari tiga hari, muntah atau diare selama lebih dari dua hari, riwayat operasi dalam waktu beberapa bulan sebelum masuk rumah sakit, penyakit akut atau kronis yang tidak stabil selama tiga minggu sebelum masuk rumah sakit, serta adanya diagnosis kanker dan 
Tabel 5. Analisis Multivariat Pengaruh Sembilan Macam Perubahan Status Gizi Spesifik terhadap Lama Rawat Inap

\begin{tabular}{|c|c|c|c|}
\hline \multicolumn{2}{|c|}{ SGA } & \multirow{2}{*}{$\begin{array}{l}\text { Jumlah } \\
\text { Subjek }\end{array}$} & \multirow{2}{*}{$\begin{array}{c}\text { Lama Rawat Inap } \\
\text { (hari) }^{2}\end{array}$} \\
\hline Masuk RS & Keluar RS & & \\
\hline Baik & Baik & 72 & $9^{1} \pm 2,09$ \\
\hline Baik & Sedang & 32 & $12^{1} \pm 2,28$ \\
\hline Baik & Buruk & 10 & $17^{1} \pm 3,11$ \\
\hline Sedang & Baik & 68 & $11^{1} \pm 2,09$ \\
\hline Sedang & Sedang & 14 & $11^{1} \pm 2,78$ \\
\hline Sedang & Buruk & 32 & $15^{1} \pm 2,38$ \\
\hline Buruk & Baik & 12 & $10^{1} \pm 2,52$ \\
\hline Buruk & Sedang & 11 & $9^{1} \pm 2,70$ \\
\hline Buruk & Buruk & 11 & $10^{1} \pm 3,12$ \\
\hline
\end{tabular}

kelainan sistem pencernaan (6). Subjek penelitian Messner et al, dan Robinson et al, $(8,9)$ yang mengalami malnutrisi mempunyai diagnosis kelainan sistem pencernaan dan liver serta kanker dan pnemonia kronis yang lebih banyak dibandingkan dengan subjek berstatus gizi normal. Chima et al. (10) menemukan bahwa tingginya derajat malnutrisi pada kelompok subjek penelitiannya yang diidentifikasi sebagai malnutrisi disebabkan karena tingginya insiden penyakit kronis pada kelompok subjek tersebut dan juga distribusi umur yang sebagian besar lebih tua dibandingkan dengan kelompok subjek yang tidak malnutrisi. Oleh karena itu Braunschweig et al (4) dalam analisis datanya mengendalikan faktor ada/tidaknya diagnosis kanker dan diabetes, riwayat operasi, serta jenis kelamin dan umur. Dengan demikian maka penelitian ini juga memasukkan faktor-faktor diagnosis penyakit, ada/ tidaknya riwayat rawat inap dan operasi dalam enam bulan terakhir, umur, jenis kelamin, serta asupan energi dan protein sebagai variabel luar yang dikendalikan.

\section{Pengaruh Penurunan Status Gizi terhadap Biaya Rumah Sakit}

Hasil analisis multivariat untuk mengetahui pengaruh sembilan macam perubahan status gizi spesifik terhadap kelompok biaya rumah sakit ditampilkan pada Tabel 7. Hasil ini diperoleh setelah mempertimbangkan faktor-faktor luar. Subjek yang mengalami penurunan status gizi dari baik menjadi sedang dan sedang menjadi buruk berisiko mengeluarkan biaya 3,27 dan 1,76 kali lebih besar daripada subjek yang tetap berstatus gizi baik selama dirawat inap di rumah sakit $(95 \% \mathrm{Cl}=1,123-9,529$; $0,590-5,245)$. Sedangkan subjek yang mengalami penurunan status gizi dari baik menjadi buruk menghasilkan nilai OR, p, maupun $95 \% \mathrm{Cl}$ tak terhingga yang menunjukkan bahwa penurunan dari baik menjadi buruk berpengaruh sangat signifikan terhadap biaya rumah sakit yang lebih besar.

Berdasarkan empat macam perubahan status gizi, subjek yang status gizinya menurun berisiko mengeluarkan biaya 2,90 kali lebih besar dibanding

Tabel 6. Analisis Multivariat Pengaruh Empat Macam Perubahan Status Gizi terhadap Lama Rawat Inap

\begin{tabular}{lcc}
\hline \multicolumn{1}{c}{ Perubahan } & Jumlah & Lama Rawat Inap \\
\multicolumn{1}{c}{ Status Gizi } & Subjek & (hari) $^{2}$ \\
\hline Normal ${ }^{2}$ & 72 & $9^{1} \pm 2,09$ \\
Meningkat & 32 & $10^{1} \pm 2,01$ \\
Tetap & 10 & $10^{1} \pm 2,52$ \\
Menurun & 68 & $14^{1} \pm 2,14$ \\
\hline
\end{tabular}

Keterangan: ${ }^{1}=$ signifikan dengan $\mathrm{p}<0,05$

$2=$ mean \pm standar error (analisis regresi linier berganda) 
subjek yang status gizinya tetap baik sebagai kelompok referensi $(95 \% \mathrm{Cl}=1,221-6,900)$. Sedangkan subjek yang status gizinya meningkat dan tetap, berturut-turut hanya berisiko mengeluarkan biaya 1,85 dan 1,86 kali lebih besar dibanding kelompok referensi $(95 \% \mathrm{Cl}=0,881-3,890 ; 0,572-6,046)$ (Tabel 8). mengeluarkan rata-rata biaya sebesar Rp. 1.782.507, terdapat selisih Rp. 271.259,-lebih besar dibanding kelompok referensi (Rp.1.511.248,-). Sedangkan subjek berstatus gizi meningkat dan tetap berturut-turut mengeluarkan rata-rata biaya $\mathrm{Rp}$. 1.653.880,-dan Rp.1.654.797,-, dengan selisih berturut-turut sebesar

Tabel 7. Analisis Multivariat Pengaruh Sembilan Macam Perubahan Status Gizi Spesifik terhadap Kelompok Biaya Rumah Sakit

\begin{tabular}{|c|c|c|c|c|c|c|}
\hline \multicolumn{2}{|c|}{ SGA } & \multirow[t]{2}{*}{ Jumlah } & \multicolumn{3}{|c|}{ Biaya Rumah Sakit ${ }^{2}$} & \multirow[t]{2}{*}{$\chi^{2}$} \\
\hline Masuk RS & Keluar RS & & OR & $\mathbf{P}$ & $95 \% \mathrm{Cl}$ & \\
\hline Baik & Baik & 72 & 1,0 & 1,0 & 1,0 & \\
\hline Baik & Sedang & 32 & 3,27 & $0,030^{1}$ & $1,123-9,529$ & $0,130^{3}$ \\
\hline Baik & Buruk & 10 & - & - & - & \\
\hline Sedang & Baik & 68 & 2,10 & 0,063 & $0,962-4,603$ & \\
\hline Sedang & Sedang & 14 & 2,58 & 0,185 & $0,635-10,556$ & \\
\hline Sedang & Buruk & 32 & 1,76 & 0,311 & $0,590-5,245$ & \\
\hline Buruk & Baik & 12 & 0,94 & 0,939 & 0,193-4,581 & \\
\hline Buruk & Sedang & 11 & 1,32 & 0,714 & 0,299-5,824 & \\
\hline Buruk & Buruk & 11 & 1,15 & 0,874 & 0,199-6,700 & \\
\hline
\end{tabular}

Keterangan: ${ }^{1}=$ signifikan dengan $\mathrm{p}<0,05$ (analisis regresi logistik)

${ }^{2}=$ biaya RSłtinggi=>Rp.1.100.000,-; rendah $=$ Rp.1.100.000,-

$3=p>0,05$ (analisis goodness of fit)

Jika total biaya tidak dikelompokkan (data kontinu), maka digunakan uji statistik regresi linier berganda. Subjek yang mengalami perubahan status gizi dari baik menjadi sedang, baik menjadi buruk, dan sedang menjadi buruk mengeluarkan rata-rata biaya rumah sakit berturut-turut sebesar $\mathrm{Rp}$. 1.690.071,-; Rp. 2.783.106,-; dan Rp. 1.907.710,-(subjek yang status gizinya tetap baik sampai dengan keluar rumah sakit hanya mengeluarkan biaya ratarata Rp. 1.563.949,). Hal ini berarti terdapat selisih berturut-turut sebesar Rp. 252.118,-; Rp. 1.087.070,; dan Rp. 337.460,-, jumlah yang cukup berarti bagi rata-rata subjek, mengingat bahwa sebanyak 49,6 persen subjek mempunyai pendapatan kurang atau sama dengan Rp.800.000,-dan 34,3 persen mempunyai pengeluaran kurang dari Rp.750.000,-(Tabel 9).

Berdasarkan empat macam perubahan status gizi pada Tabel 10, subjek berstatus gizi menurun
Rp.142.632,-dan Rp.143.549,--

Hasil ini sejalan pula dengan hasil penelitian Braunschweig et al. (4) yang menemukan bahwa pasien yang mengalami penurunan status gizi dari baik pada saat masuk rumah sakit menjadi sedang, baik menjadi buruk, dan sedang menjadi buruk pada saat keluar rumah sakit mengeluarkan biaya berturutturut sebanyak $\$ 38,289 ; \$ 66,649$; dan $\$ 50,263$, jauh lebih besar dibandingkan dengan biaya yang dikeluarkan oleh pasien yang status gizinya tetap baik sampai dengan keluar rumah sakit yang hanya sebesar $\$ 28,631$. Sedangkan Robinson et al. (9) menemukan bahwa pasien yang malnutrisi dan borderline mengeluarkan biaya rata-rata $\$ 16,691$ dan $\$ 14,118$ (vs $\$ 7,692)$.

Hal ini juga sesuai dengan penelitian yang menyimpulkan bahwa pasien yang mempunyai lebih

Tabel 8. Analisis Multivariat Pengaruh Empat Macam Perubahan Status Gizi terhadap Kelompok Biaya Rumah Sakit

\begin{tabular}{lccccc}
\hline Perubahan Status Gizi & Jumlah & \multicolumn{3}{c}{ Biaya Rumah Sakit $^{2}$} & $\boldsymbol{\chi}^{2}$ \\
\cline { 2 - 5 } & & OR & P & 95\% Cl \\
\hline Normal $®$ & 72 & 1 & & & $0,140^{3}$ \\
Meningkat & 91 & 1,85 & 0,104 & $0,881-3,890$ & \\
Tetap & 25 & 1,86 & 0,302 & $0,572-6,046$ & \\
Menurun & 74 & 2,90 & $0,016^{1}$ & $1,221-6,900$ & \\
\hline
\end{tabular}

Keterangan: ${ }^{1}=$ signifikan dengan $\mathrm{p}<0,05$ (analisis regresi logistik)

2 = biaya RSłtinggi $=>$ Rp.1.100.000,-; rendah $=\leq$ Rp.1.100.000,-

$3=p>0,05$ (analisis goodness of fit) 
banyak risiko malnutrisi di rumah sakit secara signifikan mengeluarkan biaya yang lebih besar daripada pasien yang tidak mempunyai risiko malnutrisi $(6,10)$. Naber et al. (11) menemukan bahwa pasien yang berisiko malnutrisi mengeluarkan biaya rata-rata sebesar $\$ 6,196$, sedangkan pasienyang tidak berisiko malnutrisi hanya mengeluarkan biaya rata-rata $\$ 4,563$.

Lebih jauh lagi penelitian Smith dan Smith (6) menyimpulkan pentingnya memberikan perawatan gizi (nutrition care) berkualitas tinggi bagi pasienpasien yang mempunyai risiko malnutrisi karena
Dalam penelitiannya ditemukan bahwa jika seluruh pasien yang mempunyai risiko malnutrisi diberi perawatan gizi berkualitas tinggi, maka potensial biaya yang dapat dihemat adalah sebesar $\$ 1,064$ per pasien.

Hal ini didukung pula oleh hasil-hasil penelitian Braunschweig et al., Chu, et al., dan Wyszynski et al. $(4,12,5)$ yang menyimpulkan bahwa pelayanan gizi yang baik sangat menentukan status gizi pasien selama di rumah sakit. Dukungan gizi diharapkan setidaknya dapat mempertahankan status gizi pasien selama dirawat inap sehingga dapat mencegah

Tabel 9. Pengaruh Sembilan Macam Perubahan Status Gizi Spesifik terhadap Biaya Rumah Sakit

\begin{tabular}{lccc}
\hline \multicolumn{1}{c}{ SGA } & & Jumlah Subjek & $\begin{array}{c}\text { Biaya Rumah Sakit } \\
\text { (Rp juta) }\end{array}$ \\
\cline { 1 - 2 } Masuk RS & Keluar RS & & $1,563.949^{1} \pm 297439,7$ \\
Baik & Baik & 72 & $1,690.071^{1} \pm 321246,1$ \\
Baik & Sedang & 32 & $2,783.106^{1} \pm 437296$ \\
Baik & Buruk & 10 & $1,674.434^{1} \pm 294459,8$ \\
Sedang & Baik & 68 & $1,740.380^{1} \pm 391551,9$ \\
Sedang & Sedang & 14 & $1,907.710^{1} \pm 334697,5$ \\
Sedang & Buruk & 32 & $1,576.808^{1} \pm 354175,3$ \\
Buruk & Baik & 12 & $1,879.420^{1} \pm 380246,7$ \\
Buruk & Sedang & 11 & $1,781.923^{1} \pm 438623,9$ \\
Buruk & Buruk & 11 &
\end{tabular}

Keterangan: ${ }^{1}=$ signifikan dengan $\mathrm{p}<0,05$

$2=$ mean \pm standar error (analisis regresi ganda linier)

dapat meningkatkan outcome-outcome klinis dan biaya rumah sakit yang dapat dihemat. Penelitiannya mengkategorikan perawatan gizi menjadi tiga macam, yaitu perawatan gizi berkualitas tinggi meliputi intervensi dini dengan produk gizi atau makanan spesial untuk meningkatkan asupan energi dan protein pasien dan pelayanan gizi klinis secara teratur selama pasien dirawat inap di rumah sakit; perawatan gizi berkualitas menengah hanya meliputi salah satu dari intervensi gizi dini atau pelayanan gizi klinis secara teratur; serta perawatan gizi berkualitas rendah yang tidak meliputi satupun dari intervensi gizi dini maupun pelayanan gizi klinis secara teratur. penurunan status gizi. Ahli gizi harus memprioritaskan berbagai upaya untuk meminimalkan penurunan status gizi pasien selama dirawat inap.

Hal ini sangat penting dilakukan karena status gizi yang baik pada pasien rawat inap dapat meningkatkan respon pasien terhadap terapi yang dilakukan oleh tenaga medis dan juga menurunkan insiden infeksi, komplikasi, dan mempersingkat waktu pemulihan kesehatan setelah sakit (13). Oleh karena itu monitoring status gizi pasien (nutritional screening and assessment) pada saat masuk dan menjelang keluar rumah sakit sangat penting untuk mendeteksi dan menghindari malnutrisi di rumah sakit (12).

Tabel 10. Analisis Multivariat Pengaruh Empat Macam Perubahan Status Gizi terhadap Biaya Rumah Sakit

\begin{tabular}{lcc}
\hline $\begin{array}{c}\text { Perubahan } \\
\text { Status Gizi }\end{array}$ & Jumlah Subjek & $\begin{array}{c}\text { Biaya Rumah Sakit } \\
(\text { Rp juta) })^{2}\end{array}$ \\
\hline Normal $\AA$ & 72 & $1,511.248^{1} \pm 303128,4$ \\
Meningkat & 32 & $1,653.880^{1} \pm 291427,9$ \\
Tetap & 10 & $1,654.797^{1} \pm 365753,4$ \\
Menurun & 68 & $1,782.507^{1} \pm 310761,1$ \\
\hline Keterangan: $^{1}=$ & signifikan dengan p<0,05 \\
& $2=$ & mean \pm standar error (analisis regresi linier berganda)
\end{tabular}




\section{KESIMPULAN DAN SARAN}

Perubahan status gizi subjek dari baik menjadi sedang, baik menjadi buruk, dan sedang menjadi buruk berpengaruh secara signifikan terhadap lama rawat inap yang lebih panjang dibandingkan dengan subjek yang berstatus gizi baik selama dirawat inap di rumah sakit. Subjek berstatus gizi dari baik menjadi sedang dan baik menjadi buruk mengeluarkan biaya yang lebih besar dibandingkan dengan subjek yang berstatus gizi baik selama dirawat inap di rumah sakit.

Saran untuk ahli gizi rumah sakit adalah perlu dilakukan pengukuran status gizi pasien rawat inap pada saat masuk maupun pada saat keluar rumah sakit untuk dapat meminimalkan penurunan status gizi pasien selama dirawat inap. Ahli gizi rumah sakit diharapkan dapat bekerja sama dengan profesi lainnya dalam menangani pasien rawat inap, untuk itu perlu ditingkatkan pendidikannya baik formal maupun nonformal.

Saran untuk direksi rumah sakit adalah perlu ditingkatkan kualitas dan kuantitas instrumen pengukuran status gizi pasien agar dapat menunjang intervensi pelayanan gizi berkualitas. Juga perlu memberikan kesempatan seluas-luasnya bagi ahli gizi rumah sakit untuk meningkatkan pendidikan formal dan nonformal dalam upaya menciptakan iklim kondusif bagi kerja sama lintas profesi dalam menangani pasien.

Saran untuk Departemen Kesehatan RI adalah perlu mengadakan berbagai pelatihan untuk meningkatkan keahlian ahli gizi dan perlu memberi kemudahan birokrasi bagi ahli gizi dalam meningkatkan pendidikan formal.

\section{Ucapan Terima Kasih}

Penulis mengucapkan terima kasih kepada Direktur dan Kepala Ruangan Rawat Inap Bangsal Penyakit Dalam dan Saraf RSUP Dr.Sardjito, RSUP Dr. M. Jamil, dan RSUP Sanglah, para enumerator, supervisor, dan tak lupa pula Bapak/lbu/saudara yang telah bersedia menjadi subjek penelitian, serta semua pihak yang telah ikut berkontribusi dalam penyelesaian penelitian ini yang tidak dapat disebutkan satu persatu.

\section{RUJUKAN}

1. Fischer FE. The dietitian in the hospital setting. In: Schneider HA, Anderson CE, Coursin DB, editors. Nutritional support of medical practice. Hargerstown: Medical Department Harper \& Row Publishers; 1977.
2. Weinsier RL, Hunker EM, Krumdieck CL, et al. Hospital malnutrition. A prospective evaluation of general medical patients during the course of hospitalization. Am J Clin Nutr 1979;32:418-26.

3. McWhirter JP, and Pennington CR. Incidence and recognition of malnutrition in hospital. British Medical Journal 1994;308:945-948.

4. Braunschweig C, Gomez S, and Sheean PM. Impact of declines in nutritional status on outcomes in adult patients hospitalized for more than 7 days. J Am Diet Assoc 2000;100:1316-22.

5. Wyszynski DF, Crivelli A, Ezquerro S, et al. Assessment of nutritional status in a population of recently hospitalized patients. Medicina (B Aires) 1998;58:51-7.

6. Smith PE, and Smith A. High nutritional interventions reduce costs. Healthcare Financial Management 1997;66-9.

7. Detsky AS, McLaughlin JR, Baker JP, et al. What is subjective global assessment of nutritional status? JPEN 1987;11:8-13.

8. Messner RL, Stephens N, Wheeler WE, et al. Effect of admission nutritional status on length of stay. Society of Gastroenterology Nurses and Associates 1991;202-5.

9. Robinson RN, Goldstein MSN, and Levine GM. Impact of nutritional status on DRG length of stay. JPEN 1987;11(1):49-51.

10. Chima CS, Barco K, Dewitt ML, et al. Relationship of nutritional status to length of stay, hospital costs and discharge status of patient hospitalized in the medicine service. J Am Diet Assoc 1997;97(9):975-8.

11. Naber THJ, Schermer T, Bree A, et al. Prevalence of malnutrition in nonsurgical hospitalized patients and its association with disease complication. Am J Clin Nutr 1997;97(66):1232-9.

12. Chu L., Eberhardie C, Forte D, et al. An audit of measuring equipment in elderly care. Professional Nurse 1999;14(7):463-6.

13. Rackow JR. Nutritional care of the patients in office practice. Hargerstown: Medical Department Harper \& Row Publishers; 1981. 